American Research Journal of English and Literature

ISSN(Online): 2378-9026

Volume 5, Issue 1, 2019, 1-10 Pages

DOI: 10.21694/2378-9026.19005

AMERICAN RESEARCH JOURNALS

An Academic Publishing House

\title{
Abdication under Senile Insouciance and that under Renunciation: A Comparison of Shakespeare's King Lear and the Bodhisattva King Makhadeva
}

\begin{abstract}
E. A. Gamini Fonseka, PhD
Senior Professor in English, Department of English \& Linguistics, University of Ruhuna, MATARA, Sri Lanka. drgamini@gmail.com

Abstract: While Shakespeare's King Lear is known for abdication in English literature, the Bodhisattva King Makhadeva is known for the same in the Canonical Buddhist literature. In terms of abdication, Lear gives up his responsibilities as King of Britain, while the Bodhisattva King Makhadeva renounces not only his responsibilities but also his throne and kingdom as a whole. Out of senile insouciance, Lear looks forward to an elegant retirement, never short of the royal regale he has been used to, while Makhadeva, still a man of physical vigour who has just seen the very first grey hair on his head, warned by the forebodings of senile decay, takes heed to achieve spiritual advancement before death. After abdication Lear proves the most unfortunate and pathetic tragic hero in all of Shakespeare's plays while Makhadeva remains a role model for the Buddhists all over the world to follow in the face of old age. Thus, as much as the prospects they hold in the event of abdication, do contrast the returns they experience. Focused on the post-abdication escapades of the two kings, this paper attempts to make a comparison of their characters in light of the moral, social, and didactic implications of their decisions in the context of the values and ethics they are both exposed to in their respective cultures that influence their response to the vicissitudes of life.
\end{abstract}

Keywords: King Lear, Makhadeva, Abdication, Abandonment, Renunciation, Frustration, Emancipation, Kingdom of God, Nirvana

\section{INTRODUCTION}

\section{Objectives, Research Problem, and Significance}

The objective of the paper is to analyse the characters of King Lear and King Makhadeva as protagonists from two canonical works of literature, and investigate the role their cultures and ideologies play in determining their destinies as abdicators. The main focus is on the values inculcated in the two protagonists by the respective religions they follow within their respective communities, i.e., Christianity and Buddhism, and how those values impact either negatively or positively their confrontation with the vicissitudes of life. It is realised that the Kingdom of God and Nirvana as goals of life in the two religions take two different stances in grooming an individual to come to terms with the challenges of life. Therefore, the paper attempts to study the characters in light of the religions they follow. As there are hardly any comparative studies of Shakespearean plays and narratives from canonical Buddhist literature, this appears a rare piece of research helping to open new vistas in the study of comparative literature.

\section{METHODOLOGY}

As the study involves the characters of Lear and Makhadeva as two kings who abdicate in two different narratives from two different cultures, the methodology focuses on a critical comparison of their actions and the circumstances that influence the results they differently experience thereafter. In that respect, the paper 1) studies different definitions of abdication, 2) identifies the characters of Lear and Makhadeva as abdicators, 3) familiarises the act of abdication as imagined by Lear and Makhadeva respectively, 4) reviews the post- 
Abdication under Senile Insouciance and that under Renunciation: A Comparison of Shakespeare's King Lear and the Bodhisattva King Makhadeva

abdication escapades of Lear and Makhadeva, 5) compares the destinies of Holinshed's Lear with that of Shakespeare's Lear in light of fatalism, 6) analyses Lear's and Makhadeva's perceptions of the vicissitudes of life, 7) investigates the ideological and cultural implications of Lear's and Makhadeva's abdication, and 8) assesses the two narratives in light of didacticism. As the discussion involves several concepts particular to Buddhism, it is attempted to define them as and when they appear.

\section{RESULTS AND FINDINGS}

In the character analyses of the two kings as protagonists, this paper demonstrates how their respective cultures impact their attitudes to sovereignty, decisions for abdication, and expectations for post-abdication returns. The attitudes they hold towards the vicissitudes of life look vital in the comparison of the circumstances that determine their destinies. The perception of life Makhadeva maintains, coming from a Buddhist culture, and that Lear maintains, coming from a Christian culture, distinguish from each other in the returns they experience in their post-abdication escapades, and the ways in which they put up with life. The paper helps to realise how the concepts of the Kingdom of God and Nirvana clash with each other while impacting the two respective protagonists' alertness to the circumstances of life, and what to pick from their destinies in light of didacticism.

\section{DEFinitions OF ABDication}

"Abdication" as defined in Dictionary.com has two meanings; "an act of abdicating or renouncing the throne" and "failure to fulfil a responsibility or duty". The two definitions of "abdication" given in Cambridge Dictionary are in the same contexts and read as "the fact of no longer controlling or managing something that you are in charge of" and "an occasion when a king or queen makes a formal statement that he or she no longer wants to be king or queen". In the same contexts, the Merriam-Webster Dictionary defines abdication as "an act of giving up sovereign power or high office" and "an act of abandoning or discarding a right, responsibility, etc." When all these three sets of definitions are put together it is possible to formulate intelligent definitions of what the two respective kings, Lear and Makhadeva, do in terms of abdication.

\section{The Characters of Lear and Makhadeva as Abdicators}

The two kings in question, Lear and Makhadeva, are from two classical sources as said before. Lear has earned so much reputation among theatregoers, dramatists, critics, as well as psychologists as the protagonist in William Shakespeare's (1606) tragic play King Lear. Shakespeare adopted the story of "King Lear" from The Chronicles of England, Scotland and Ireland written by Raphaell Holinshed (1577), and adapted it for the theatre as a tragic hero with some significant changes to the character of Lear. As a result the Lear in Shakespeare's play is deprived of the victory that in Holinshed's story makes in the war against his ungrateful daughters and their husbands, his restoration as King of Britain with the support of his youngest daughter whose position about filial love for her father he totally misunderstood, and the peaceful death he enjoys two years later as a monarch. Two centuries after Shakespeare's production of the play, Charles Lamb reproduced the story of "King Lear" as a prose narrative for his Tales from Shakespeare, published in 1807, being faithful to Shakespeare's version.

Although he comes from a totally different culture in Asia, Makhadeva parallels with Lear in several ways but in a contrasting manner. Makhadeva, a king in the realm of Videha in Mithilā, is the protagonist in Jataka Story No. 9. "Makhādeva-Jātaka" in The Jataka (crica 380 BCE) in Buddhist canonical literature, translated from the Pali into English by Robert Chalmers in 1895. Like the other jataka stories that were composed to illustrate how the Buddha fulfilled the prerequisites of Buddhahood in his former births as Bodhisattwa, this was composed to demonstrate his practice of renunciation. In Sri Lanka, the Buddhists perform song recitals and dramatized versions of the story at annual Buddhist festivals, inspired by the metrical version of it in Sinhala dated to the $15^{\text {th }}$ or $16^{\text {th }}$ Century CE (Wickremasinghe, 1900), as it has so much relevance and significance to the life of a Buddhist. (See Gunadasa, 2018) 
Abdication under Senile Insouciance and that under Renunciation: A Comparison of Shakespeare's King Lear and the Bodhisattva King Makhadeva

\section{Abdication as Imagined by Lear and Makhadeva Respectively}

Lear's age at the moment of his abdication, can be figured out from the age-related issues in his physical and mental condition that appear in Holinshed's (1577) chronicle as "... this Lear therefore was come to great years and began to wax unwieldy through age...", Shakespeare's composition of Lear's daughter Goneril's complaint on her father on "the unruly waywardness / that infirm and choleric years bring with them" (King Lear, Act 1, Sc 2) and Lamb's (1807) estimation of his age as "more than fourscore years". In Makhadeva's story, while the life expectancy of the king is calculated as 4 phases, each spanning over a similar period of time, he renounces his kingdom at the end of the $3^{\text {rd }}$ phase. Being mature men, both Lear and Makhadeva consider abdication a necessary step one must take at a certain stage in life. Lear's decision to abdicate is obviously forced by his old age, lack of physical and mental strength, and desire to prepare for his upcoming death.

The old king, worn out with age and the fatigues of government, he being more than fourscore years old, determined to take no further part in state affairs, but to leave the management to younger strengths, that he might have time to prepare for death, which must at no long period ensue. (Lamb, 1807)

In the stage play King Lear, he declares his abdication at the royal court in the following terms:

and 'tis our fast intent

To shake all cares and business from our age;

Conferring them on younger strengths, while we

Unburthen'd crawl toward death. (Shakespeare 1606, Lear, Act 1, Sc 1)

Here, it is clear that, while perceiving his age, Lear wants to free himself from his royal responsibilities and duties, and lead his life until his death without any burden. He plans to divide his kingdom into three and appoint the husbands of his three daughters as the kings of the three kingdoms that emerge from the division.

In a similar mood Makhadeva declares his abdication as follows:

He sent for his eldest son and said to him, "My son, grey hairs are come upon me, and I am become old. I have had my fill of human joys, and fain would taste the joys divine; the time for my renunciation has come. Take the sovereignty upon yourself; as for me, I will take up my abode in the pleasance called Makhādeva's Mango-grove, and there tread the ascetic's path." And after these words, he renounced his sovereignty that self-same day and became a recluse. (Chalmers: 1895)

Because of his emphasis on "old age", "death", and "freedom", on the surface, Makhadeva's declaration sounds more or less the same as Lear's. Yet his intention of abdication is very clear in his zeal to "taste the joys divine" and his wish to become "an ascetic", and his plan to reside in a "mango grove" until his death.

From the declarations they each make, it is surmised that Lear's abdication means "an act of giving up responsibility" and Makhadeva's abdication means a total "renunciation" of his kingship. What Lear is going to do thereafter is not clear at all. So it is interpreted here as "a matter of senile insouciance" -"a relaxed and happy way of behaving without feeling worried or guilty of any commitment to the public due to poor mental ability because of old age, especially being unable to think clearly and make decisions" (adapted from Cambridge Dictionary).The subjection of his freedom to an unreasonably parsimonious and ruthlessly uncompromising group thereby appears as a result of the faux pas he makes in terms of abdicating. In Aristotelian terms, his dependence on his two eldest daughters can be interpreted as a tragic flaw in his character as the protagonist of the play (brooklyn.cuny.edu) 
Abdication under Senile Insouciance and that under Renunciation: A Comparison of Shakespeare's King Lear and the Bodhisattva King Makhadeva

\section{Post-Abdication Escapades of Lear and Makhadeva}

In fact the post-abdication escapades the two individuals have further imply the real intentions of their respective abdication decisions. Lear in The Chronicles of England, Scotland and Ireland, which is considered an authentic record, was destined to lead his life pathetically, "put to his portion, that is, to live after a rate assigned to him for the maintenance of his estate, which in process of time was diminished as well by Maglanus as by Henninus ... and ... brought to that misery that scarcely they would allow him one servant to wait upon him" (Holinshed, 1577). The disappointment and disillusionment Lear thus harbours against his two eldest daughters resonate even more violently in Shakespeare's play King Lear where they argue on the issue of accommodating a retinue of a hundred knights in ungrateful and unsympathetic exchanges that come to a conclusion in Lear's famous soliloquy:

No, you unnatural hags,

I will have such revenges on you both, That all the world shall--I will do such things,--

What they are, yet I know not: but they shall be

The terrors of the earth. You think I'll weep

No, I'll not weep:

I have full cause of weeping; but this heart

Shall break into a hundred thousand flaws,

Or ere I'll weep. 0 fool, I shall go mad! (King Lear, Act II Sc. Iii)

Thus Lear, unable to believe the wicked attitudes of his daughters, expresses his urge to take revenge on them, calling them "unnatural hags" and "The terrors of the earth". Lamb narrates Lear's nostalgia at this moment with a clear perception of the nature of a king, used to leading his life, always followed by a pompous entourage of knights and servants.

Not that a splendid train is essential to happiness, but from a king to a beggar is a hard change, from commanding millions to be without one attendant; and it was the ingratitude in his daughters' denying it, more than what he would suffer by the want of it, which pierced this poor king to the heart; insomuch, that with this double ill-usage, and vexation for having so foolishly given away a kingdom, his wits began to be unsettled, and while he said he knew not what, he vowed revenge against those unnatural hags, and to make examples of them that should be a terror to the earth! (Lamb, 1807)

Lear's grief at this point helps to determine whether what he did in terms of abdication was an act of absconding from his responsibilities or renouncing his kingdom along with all the entitlements he has had as king.

Contrasting with Lear, Makhadeva spares all these claims, complaints, conflicts, clashes, and cries, and leads a life of spiritual progress in the mango grove that he chose to reside in, striving towards the achievement of the Jhanas that are prescribed in Buddhism as "meditative states of profound stillness and concentration in which the mind becomes fully immersed and absorbed in the chosen object of attention"(accesstoinsight.org) as stages prerequisite to enlightenment. So after his abdication, Makhadeva leads his life all by himself and does not have anything to do with anybody.

\section{Destinies of Holinshed's Lear and Shakespeare's Lear}

The circumstances concerning Holinshed's Lear operate obviously in a more fortunate way than those concerning Shakespeare's Lear. Holinshed reports:

Hereupon, when this army and navy of ships were ready, Lear and his daughter Cordelia with her husband took the sea and, arriving in Britain, fought with their enemies and discomfited them in battle, 
Abdication under Senile Insouciance and that under Renunciation: A Comparison of Shakespeare's King Lear and the Bodhisattva King Makhadeva

in the which Maglanus and Henninus were slain; and then was Lear restored to his kingdom, which he ruled after this by the space of two years; and then died, forty years after he first began to rein. (Holinshed, 1577)

Accordingly, Lear in Holinshed's Chronicles defeats his two ungrateful eldest daughters Goneril and Regan and their cruel husbands Maglanus and Henninus with the help of his youngest daughter Cordelia and her husband Aganippus, regains his kingdom, and rules it until he dies a peaceful death after two years.

A dramatist of outstanding imagination, Shakespeare in his intertextual exercise adapts this episode negatively to suit his theatrical purpose in an effort to turn the story with a happy end into a tragedy of extraordinary emotions.

The forces which Goneril and Regan had sent out under the command of the bad Earl of Gloucester were victorious, and Cordelia, by the practices of this wicked earl, who did not like that any should stand between him and the throne, ended her life in prison. Thus, Heaven took this innocent lady to itself in her young years, after showing her to the world an illustrious example of filial duty. Lear did not long survive this kind child. (Lamb 1807)

By the changes he introduces to the plot, Shakespeare achieves an irony when Lear has to seek Cordelia's assistance in taking revenge on her ungrateful sisters, suspense in Cordelia's declaration of a war against the usurpers of her father's throne, a paradox in the deaths of Goneril and Regan entangled in a terrible conspiracy and clandestine romantic relationships, an anti-climax in Lear's loss of hope after falling victim to the crafty Edmond, the illegitimate son of Gloucester, and tremendous pathos in Cordelia's suicide in prison and Lear's lamentation over Cordelia's death. After all, the abdication Lear makes invites a disaster upon himself as well as his virtuous daughter. While Holinshed's Lear dies a king Shakespeare's Lear dies a raving lunatic. Thus Shakespeare takes the dark side of abdication in a philosophical approach to old age. The contrasting postabdication circumstances Lear faces in the two versions of his story can be interpreted in terms of fatalism. They affect the abdicator to the degree of his attachment to the material prospects of his life. Shakespeare thus allows space for weighing the pros and cons of abdication in a world of corruption, distrust, and evil.

\section{Lear's and Makhadeva's Perceptions of the Vicissitudes of Life}

In a comparison of the two characters - Lear and Makhadeva - a basic idea about the vicissitudes of life is crucial because the post-abdication results they enjoy or suffer can be interpreted in terms of their perceptions of the vicissitudes of life. "Vicissitude" means "natural change or mutation visible in nature or in human affairs" (Merriam-Webster). In the English language it generates meaning only when it is used in the plural. So it is defined as "changes that happen at different times during the life or development of someone or something, especially those that result in conditions being worse" (Cambridge Dictionary). Lear in the narratives of both Holinshed and Shakespeare does not tend to understand whether one should get mentally adjusted to the natural changes in life and whether one should free oneself from certain ceremonial or hedonistic extravagances in one's old age. In both narratives Lear aspires to maintain a debonair royal personality, imposes expensive liabilities, and invites encumbrances upon himself just for the sake of showing off his royal position as a king full of pomp and power. Though Holinshed's Lear recovers his kingdom by waging war against his two eldest daughters he cannot repulse death. In two years' time he dies. Then what is the big deal about keeping it? Therefore it is clear that Lear has no notion of coming to terms with the vicissitudes of life that every being is supposed to undergo.

In this case Makhadeva is a highly cultivated personality. With his exposure to the fundamentals of the Buddhist thought, he understands the deepest truth about life:

American Research Journal of English and Literature

Page 5 
Abdication under Senile Insouciance and that under Renunciation: A Comparison of Shakespeare's King Lear and the Bodhisattva King Makhadeva

Recognition of the fact of impermanence (anichcha), suffering (dhukkha), and the absence of a self (anatta) as the three basic characteristics of existence constitutes the "right knowledge" in Buddhism (adapted from Encyclopaedia Britannica).

He perceives these characteristics common to every being as a youth growing in a society where values and ethics are formulated on the basis of these fundamentals of life. Therefore he prepares himself for his old age much in advance, having advised his barber during his youth to produce to him the very first grey hair the latter comes across in his head. He confirms it further in the proclamation he makes of his intention before his ministers who are amazed by his decision.

Lo, these grey hairs that on my head appear

Are Death's own messengers that come to rob

My life. 'Tis time I turned from worldly things,

And in the hermit's path sought saving peace. (Chalmers, 1895)

So once he realises he is getting old he does not make a fuss about it but disappears from the world of affairs. Makhadeva thus makes a smart decision under his clear perception of the vicissitudes of life.

\section{Ideological and Cultural Implications of Lear's and Makhadeva's Abdication}

It is surmised that a hard action a king takes such as the abdication or the abandonment of his sovereignty is precipitated by a decision-making process nurtured under the influence of his ideology which is predominantly composed of the "opinions or beliefs characteristic of his culture" (Vocabulary.com). “Culture can provide space and contains a variety of different ideologies even the conflicting ideologies" (Mishra 2015). The shaping of the cultures and ideologies that we thus perceive today has much to do with the religions particular to them. The pivotal role religion plays in modelling the cultural beliefs and practices in the world compels any observer to feel that religion and culture are inseparable. In that sense the connections between the decisions Lear and Makhadeva make in their respective domains and the moral and ethical influences they have drawn from their cultures are significant, in determining a way forward for them after abdication. Their moods and behaviours mirror their convictions.

Coming from a Christian background, Lear is supposed to be in harmony with the idea of the Kingdom of God which is explained in the Bible as follows:

"The Kingdom of God is the realm where God reigns supreme, and Jesus Christ is King. In this kingdom, God's authority is recognized, and his will is obeyed. The concept of a Kingdom of God is not primarily one of space, territory, or politics, as in a national kingdom, but rather one of kingly rule, reign, and sovereign control" (Fairchild, 2018).

During the mediaeval times such conceptual frameworks furnished with notions of "kingdom", reign", "supremacy and authority", "rule", "sovereign control", etc., contributed to the evolution of a political and religious doctrine of royal absolutism highlighting the divine right of the kings to rule their subjects.

It asserts that a monarch is subject to no earthly authority, deriving his right to rule directly from the will of God. The king is thus not subject to the will of his people, the aristocracy, or any other estate of the realm, including the church. The doctrine implies that any attempt to depose the king or to restrict his powers runs contrary to the will of God and may constitute treason. (Macintosh, 2018)

There is no doubt that Lear's overconfidence is a bi-product of such a religious and political mind-set established in society in this manner. His destiny after his miscalculated abdication is very much like that of King Yasalalakatissa of Sri Lanka (52 AD - 60 CE) who, while playing a practical joke, swopped his attire with 
Abdication under Senile Insouciance and that under Renunciation: A Comparison of Shakespeare's King Lear and the Bodhisattva King Makhadeva

his crafty palace gatekeeper Subha who was identical to him, allowed the latter to occupy his throne, and finally quite by accident got beheaded by the latter's order. (See Mahavamsa)

Makhadeva's idea about his kingship is totally different from that of Lear. The background provided by his culture that recognises impermanence as an irrevocable force and the ideology he developed on his own in consonance with its fundamentals confront each other in the presence of a grey hair on his head, and his reaction is related as follows:

And as he thought and thought about the appearance of his grey hair, he grew aflame within; the sweat rolled down from his body; whilst his raiment oppressed him and seemed intolerable. "This very day," thought he, "will I renounce the world for the Brother's life." (Chalmers, 1895)

The spiritual aim of a Buddhist is Nirvana which has nothing to do with any power, rule, sovereignty, or supremacy of earthly value. It is common to anybody; be he king or not.

Indeed, the simplest definition of nirvana-in-this-life is "the end of greed, hatred, and delusion". It is clear that nirvana-in-this-life is a psychological and ethical reality. It's a transformed state of personality characterized by peace, deep spiritual joy, compassion, and a refined and subtle awareness. Negative mental states and emotions such as doubt, worry, anxiety, and fear are absent from the enlightened mind. (Keown, 2019)

The above definition of Nirvana influenced by the canonical texts of Buddhism is sufficient to understand the ideology behind Makhadeva's decision. As a righteous king he has been waiting for his son to grow up to take over his kingdom and as a mature man he bravely comes to terms with the signs of his old age, knowing that it will culminate in his death. As characters the two of them, Lear and Makhadeva, distinguish with each other in their response to the universal realities explained in Buddhism. While Lear is in a limbo, Makhadeva steadily moves on in his post-abdication plans.

\section{Destinies of Lear and Makhadeva in Light of Didacticism}

"Life is tragic. But the tragedy of life can be understood only by one who sees the eidetic, or ideal, reality in the depths of this tragedy. The fate of the heroes in a Greek tragedy attests to the existence of the supreme life principles which alone are capable of giving meaning to this tragic fate. Aristotle proved this as much in his philosophical theories, and in his practical life and public activity." (Losev \& TakhoGodi, 1990)

The above explanation to Aristotle's pursuit of his theories in consolidating art and life into a single locus applies to the destinies of both Lear and Makhadeva. Lear's destiny is obviously in agreement with the parameters of a classic tragedy prescribed in Aristotle's Poetics as it generates "tragic pleasure of pity and fear" through a hero who "cannot be either all good or all evil but must be someone the audience can identify with", and whose "disastrous end results from a mistaken action, which in turn arises from a tragic flaw or from a tragic error in judgment" (Brooklyn). Lear's tragic flaw, his tragic error in judgement, and the mistaken action he commits have invited several controversies.

Not to mention the pompous, characterless language of King Lear, the same in which all Shakespeare's Kings speak, the reader, or spectator, cannot conceive that a King, however old and stupid he may be, could believe the words of the vicious daughters, with whom he had passed his whole life, and not believe his favorite daughter, but curse and banish her; and therefore the spectator, or reader, cannot share the feelings of the persons participating in this unnatural scene.(Tolstoy, 1906).

American Research Journal of English and Literature

Page 7 
Abdication under Senile Insouciance and that under Renunciation: A Comparison of Shakespeare's King Lear and the Bodhisattva King Makhadeva

Tolstoy's scepticism about Lear's limitations in decision-making that have led to a mistaken action has a clear social, cultural, and moral basis. Being the father of his three daughters, he does not seem to have perceived their characters. He trusts the two hypocritical ones and distrusts the only genuine one. Without stopping there he presents his kingdom to the two hypocritical ones and banishes the genuine one. The implication is that he empowers his enemies and impairs his friend, inviting a disaster upon himself. The tragic flaw and the error in judgement that emerge from his behaviour are not acceptable to any audience composed of parents and children. Under didacticism, the moral the audience can pick up may be that one has to be cautious while dealing with one's children, or that one has to keep life interest while giving away any wealth to one's children. For that matter one can keep one's wealth as long as one lives and ensure one's safety thereby. In that sense there is nothing original for the audience to learn from Lear's character, except for lamenting his folly and the bizarre situation he ends up in.

Compared to Lear, Makhadeva's destiny has a positive meaning and invites many anecdotal examples. The whole idea of Makhadeva's act is presented in a nutshell as follows:

"My friend, renounce the world before the world renounces you."

The applicability of Makhadeva's decision is perceived in the above maxim made by the late Professor Jotiya Dheerasekera, Professor of Buddhist Philosophy, at the University of Peradeniya (Sri Lanka), who got ordained in 1990 as a Buddhist monk in the name Dhammavihari Thera and passed away in 2010, after spending twenty years as a Buddhist monk, fully engaged in Buddhist studies and meditation (Ranatunga, 2010). An internationally renowned eminent scholar of Buddhist Philosophy in the academia became such a humble monk once he retired from his professorship. The example he sets thereby revives Makhadeva's act and is relevant to anybody from any part of the world heading for retirement in a social context today. As mentioned above Makhadeva remains a role model to follow, because of his perception of reality in the depths of the tragedy of existence which is considered a disease-like state in Buddhism (Littlefair, 2017).

\section{CONCLUSION}

To conclude, first I would like to sum up the procedure followed in the paper. As it aims at analysing comparatively the characters of Shakespeare's King Lear and the Bodhisttva King Makhadeva as two kings who abdicate with two contrast post-abdication plans and end up in two contrast destinies, attempts were made to study different definitions of abdication to interpret their actions respectively and investigate their post-abdication escapades in light of their destinies. It is surmised that their contrast perceptions of the vicissitudes of life are attributed to the ideologies they develop within their cultures. In a didactic probe into the contrasting psychological conditions of the two, it is understood that Lear's agony owes very much to the church-promoted Bible-based religious doctrine of royal absolutism in mediaeval Europe that accordedto the kingsa divine right to rule their subjects. There Makhadeva behaves as part of nature subject to decay and death and does not have any frustration. As high literature is recognised for its capacity to achieve catharsis in the audience in terms of "purgation" or "purification", or "clarification" (Essays, UK., 2018), the story of Makhadeva, a hero of tremendous endurance and magnanimity, does not miss it at all. Compared to Lear, he holds a far superior position in world literature.

\section{REFERENCES}

1. Brooklyn College English Department (2009). A Guide to the Study of Literature: A Companion Text for Core Studies 6, Landmarks of Literature [electronic resource]. New York: Brooklyn College. http://academic. brooklyn.cuny.edu/english/melani/cs6/index.html (Accessed: 17/08/2019)

2. Buddha-vachana.org. CattāroJhānā. http://www.buddha-vacana.org/formulae/4jhana.html (Accessed: 17/08/2019)

American Research Journal of English and Literature

Page 8 
Abdication under Senile Insouciance and that under Renunciation: A Comparison of Shakespeare's King Lear and the Bodhisattva King Makhadeva

3. Cambridge Dictionary https://dictionary.cambridge.org/dictionary/english/abdication (Accessed: 17/08/ 2019)

4. Dictionary.com (dictionary.com) (Accessed: 17/08/2019)

5. Encyclopaedia Britannica. https://www.britannica.com/topic/religion

6. Essays, UK. (November 2018). Psychology Catharsis And Literature Philosophy Essay. Retrieved from https://www.ukessays.com/essays/philosophy/psychology-catharsis-and-literature-philosophy-essay. php?vref=1

7. Fairchild, Mary (2019); “What Is the Kingdom of God?” Learn Religions, Apr. 17, 2019, learnreligions.com/ what-is-the-kingdom-of-god-701988. (Accessed: 17/08/2019)

8. Greek Theory of Tragedy: Aristotle's Poetics. http://academic.brooklyn.cuny.edu/english/melani/filmand-lit/tragedy-hnd.pdf (Accessed: 17/08/2019)

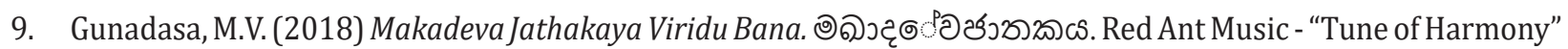
https://www.faceclips.net/video/u9MLDvTB6_k/makadeva-jath.html (Accessed: 17/08/2019)

10. Holinshed, Raphaell (1577). The Chronicles of England, Scotland and Ireland.https://www.bl.uk/collectionitems/holinsheds-chronicles-1577 (Accessed: 17/08/2019)

11. Keown, Damien (2019). "The Meaning of Nirvana in Buddhism Explained: Reaching the end of greed, hatred, and delusion." In BUDDHISM FOR BEGINNERS. HTTPS: // TRICYCLE.ORG/MAGAZINE/ NIRVANA-2 / (Accessed: 17/08/2019)

12. Lamb, Charles (1807). Tales from Shakespeare. https://ebooks.adelaide.edu.au/l/lamb/charles/talesfrom-shakespeare/(Accessed: 17/08/2019)

13. Littlefair, Sam (2017).What Is Suffering?InLion's Roar - Buddhist Wisdom for Our Time.September 8, 2017. https://www.lionsroar.com/what-is-suffering-10-buddhist-teachers-weigh-in/ (Accessed: 17/08/2019)

14. Losev, Alexei \& Aza Takho-Godi (1982). Aristotle. Moscow: Progress Publishers.

15. MAKHĀDEVA JĀTAKA [A metrical version of the early life of the Bodhisat King Makhādeva] pp 25. Colombo 1870. Catalogue of the Sinhalese printed books in the library of the British museum; _ British Museum. Dept. of Oriental Printed Books and Manuscripts. https://archive.org/details/catalogueofsinha00brituoft/ page/n73 (Accessed: 17/08/2019)

16. McIntosh, Matthew A. (2018). The 'Divine Right of Kings' in Medieval England and France. https:// brewminate.com/the-divine-right-of-kings-in-medieval-england-and-france/ (Accessed: 17/08/2019)

17. Mishra, Sanjay. "What's the difference between ideology and culture?" https://www.quora.com/Whatsthe-difference-between-ideology-and-culture (Accessed: 17/08/2019)

18. No. 9. MAKHĀDEVA-JĀTAKA. The Jataka, Volume I, tr. by Robert Chalmers, [1895], at sacred-texts.com (Accessed: 17/08/2019)

19. Ranatunga, D.C. (2010). "Renounce the world before the world renounces you, said scholar monk and mentor." Appreciation - The Venerable Dhammavihari Thera. Sunday Times. May 23, 2010. http://www. sundaytimes.lk/100523/Plus/plus_06.html (Accessed: 17/08/2019)

20. Shakespeare, William (1606). King Lear. http://shakespeare.mit.edu/lear/full.html (Accessed: 17/08/ 2019) 
Abdication under Senile Insouciance and that under Renunciation: A Comparison of Shakespeare's King Lear and the Bodhisattva King Makhadeva

21. THE MAHAVAMSA - The Great Chronicle of Sri Lanka. http://mahavamsa.org/mahavamsa/original-version/ 35-twelve-kings/ (Accessed: 17/08/2019)

22. Tolstoy, Leo (1906). Tolstoy on Shakespeare: A Critical Essay on Shakespeare. Translated by V. Tchertkoff. New York \& London: Funk \& Wagnalls Company. http://www.gutenberg.org/files/27726/27726-h/27726-h. htm (Accessed: 17/08/2019)

23. Vocabulary.com. (Accessed: 17/08/2019)

24. Wickremasinghe, Don Martino De Zilva (1900). Catalogue of the Sinhalese manuscripts in the British Museum. https://archive.org/stream/cu31924023065315/cu31924023065315_djvu.txt (Accessed: 17/08/2019)

Citation: E. A. Gamini Fonseka, "Abdication under Senile Insouciance and that under Renunciation: A Comparison of Shakespeare's King Lear and the Bodhisattva King Makhadeva", American Research Journal of English and Literature, vol 5, no. 1, 2019, pp. 1-10.

Copyright (c) 2019 E. A. Gamini Fonseka, This is an open access article distributed under the Creative Commons Attribution License, which permits unrestricted use, distribution, and reproduction in any medium, provided the original work is properly cited. 